\title{
DEVELOPMENT SOIL FERTILITY MAP BY GEOGRAPHIC INFORMATION SYSTEM TECHNOLOGY FOR AL-SOUERA
}

*M. H. M. AlBudeiri

Researcher

Coll. of Agric. - Univ. of Baghdad
Y. A. M. AL-Aloosy

Assist. Prof.

\section{ABSTRACT}

Coll. of Agric. - Univ. of Baghdad

The study area is located in Wasit province, represented in Al-Souera about 60km south of Baghdad (464273.369- 463318.982) East and (3643443.734 - 3643798.3013) North. GIS technology was used to predict some of soil fertility parameters by using Kriging Application and to produce a final fertility map by standard method of assessment, building a database of soil characteristics in GIS environmental. The results showed: There were four classes of fertility assessment in the study area, very fertile soil class was not found because the study area did not contain the ideal state of the indicators used in soil fertility assessment. The fertile soil class in the study area was $7.53 \%$ from the total area were silty clay loam texture, high organic matter, neutral $\mathrm{pH}$, moderately $\mathrm{CaCO3}$, high CEC, high contain NPK, low ECe, and low ESP. The moderately fertile soil class in the study area was $51.99 \%$ from the total area were silty clay loam texture, low organic matter, neutral $\mathrm{pH}$, high $\mathrm{CaCO3}$, high CEC, high contain NPK, low ECe, and low ESP. The slightly fertile soil class in the study area was $39.61 \%$ from the total area were silty clay loam texture, moderately organic matter, neutral $\mathrm{pH}$, high CaCO3, high CEC, high contain NPK, moderately ECe, and low ESP. The non-fertile soil class in the study area was $0.93 \%$ from study area. The soil productivity digresses because of low organic matter, high CaCO3, and high ECe.

Key words: soil fertility parameters, standard method of assessment, database, Kriging.

*Part of Ph. D. dissertation of $1^{\text {st }}$ author.

\begin{tabular}{|c|c|c|}
\hline البديري والالوسي & & ية العراقية -2019 :50(عدد خاص):203-192 \\
\hline & م تقانة نظم المعلومات الجغرافية & اث خارطة التقييم الخصوبي لمنطقة الص \\
\hline & يوسف احمد محمود الالوسي & منتظر حمادي منصور البديري \\
\hline & استاذ مساعد & باحث \\
\hline & كلية الزراعة- جامعة بغداد & كلية الزراعة- جامعة بغداد \\
\hline
\end{tabular}

Muntaze960@gmail.com

تقع منطقة الدراسة في محافظة واسط في منطقة الصويرة التي تبعد حوالي 60 كم جنوب بغداد، متمثلة بالاحاثيات (464273.369 -

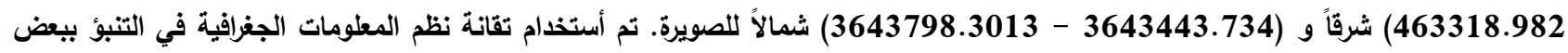
معايير خصوية التربة باستخدام تطبيق Kriging وانتاج خارطة خصويية لمنطقة الاراسة باعتماد التقييم وياستعمال طريقة الضرب القياسية. ويناء قاعدة بيانات خاصة بصفات الترية. واثشارت نتائج الاراسة الى : وجود اربعة اصناف للتربة من حيث التقييم الخصوبي في منطقة الدراسة، اذ لم يظهز صنف الترب الخصبة جداً فيها وذلك لانها لاتحتوي على الحالة المثالية للمؤشرات الداخلة في التقييم الخصوبي للتربة. بلغت نسبة صنف الترب الخصبة

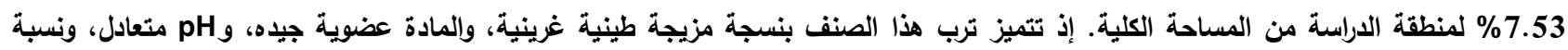
الكلس متوسطة، ونسبة CEC عالية، ومحتواه من NPK جيد، وذات ملوحة منففضة، ونسبة ESP منخفضة. بلغت نسبة صنف الترب المتوسطة

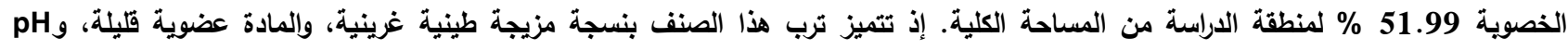

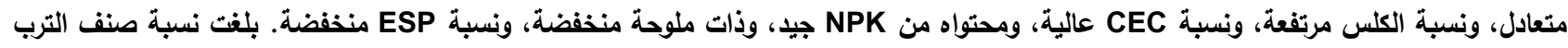

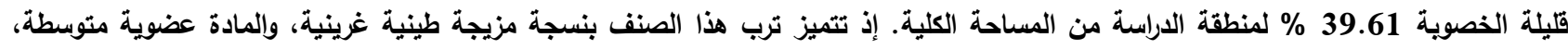
و و متعادل، ونسبة الكلس عالية، ونسبة CEC عالية، ومحتواه من NPK جيدة، وذات ملوحة متوسطة، ونسبة ESP منخفضة نسبياً. صنف الترب غير الخصبة بلغت نسبته 0.93 \% لمنطقة الدراسة من المساحة الكلية. واتخفضت القابلية الإنتاجية لهذا الصنف بسبب انخفاض مستوى المادة العضوية، وارتفاع نسبة الكلس، وارتفاع نسبة الملوحة. "البحث مستل من اطروحة دكتوراه الباحث الاول. 


\section{INTRODUCTION}

Fertility assessment is the process of estimation soil susceptibility in processing plant nutrients required for optimal growth. This assessment includes a number of processes using field and laboratory diagnostics and a number of mathematical models that link the relationship between soil nutrient level and plant responsiveness. It is necessary to know the proper way to evaluate the soil fertility status and to identify the nutrient deficiency. Soil analysis gives a clear value for improving the efficiency of fertilizers. Nitrogen, phosphorus and potassium are the main determinants of crop growth $(4 ; 13)$. The traditional soil survey gives information on soil fertility patterns and soil management, and plant size gives evidence of plant response to soil properties and management often based on soil analysis. Therefore, current soil testing methods are not feasible or weak in production forecasting, careful and consistent change, continuously changing and changing soils that affect nutrient availability and vulnerability in careful nutrient mineral screening and nutrient response (3). In view of the danger of diminishing water resources in large areas of the world, including Iraq, the urgent demand for increased agricultural production to avoid global food shortages and the serious climate change facing humanity, there has been a need to use some modern means and assist in the implementation of natural resource inventories, And GIS applications (8). This progress has helped to achieve the utmost accuracy in obtaining information sent from satellites and solving many issues related to land and natural conditions, through the amount of information provided and processed digital processing by high technology, GIS was used to predict the soil content of available phosphorus by Kriging application (6). The use of geographic information systems (GIS) software has an effective and very useful effect in modifying maps of the soil and soil classification from the relevant authorities. Use(11) the Kringing application, spatial prediction of some of the chemical and physical soils properties texture, salinity, calcium carbonate, gypsum and ESP - was produced as a mapping to serve research and application work in southern Iraq. The production of suitable land maps for agriculture is important in agricultural planning and crop distribution as appropriate for soil, as well as monitoring the status of plant nutrition with the stages of growth and the treatment of any defect (10). And the prediction of maturity, harvest and marketing dates, as well as emphasis on the investment of high fertility and high productivity land, the availability of production requirements in the first instance and addressing the shortage of soil fertility (18). To detect the correlation between spectral reflectivity and some of the surface soil characteristics of the Lower Salman area in southern Iraq, there was no significant correlation between reflectivity and organic matter content, gypsum and calcite due to homogeneous distribution within the study area (19). That the adoption of these technologies as based on a high degree of compatibility with field surveys and because the study of soil fertility in the Iraqi soil is limited to specific site measurements and narrow is the farms of agricultural research centers or land belonging to the faculties of agriculture will be adopted for remote sensing and information systems To prepare soil fertility maps as well as to diagnose fertility sites (1).

\section{MATERIALS AND METHODS}

The study area Al-Souera (S) was selected in the province of Wasit area of the area of 173 $\mathrm{km}$, which is located south of the capital Baghdad, and about $60 \mathrm{~km}$, according to the following coordinates: (464273.369582463318.982592) east and (3643443.73432 3643798.30132) north, classified within the groups Typical Great Torrifluvent (15). The period of more than six months with low rainfall, the soil of this area was characterized by a system of Torric (Aridic); Soil is severely dehydrated for more than 90 nature of the hot summer for a day, and the average temperature annual of soil, which rises to more than $30^{\circ} \mathrm{C}$. As well as the difference between the temperature of the soil in summer and winter and more than $10^{\circ} \mathrm{C}$ obtained by thermal system of the class of Hyper thermal. 70 sites were selected from the study area and representative samples were taken from the depth $(0-30 \mathrm{~cm})$. Using GPS, (Carmen) with 
the UTM system, the Coordinates of the soil sample sites in the study Area were read and spatially dropped in ArcGIS10.4, For the purpose of satisfying the requirements of spatial analysis and finding robust models for predicting soil characteristics derived from space data. The samples were analyzed and analyzed from a $2 \mathrm{~mm}$ diameter sieve with the following chemical and physical analyzes: Physical properties (7) were estimated. ESP (12) estimated the reciprocity of ketones, carbonate minerals, organic matter, $\mathrm{pH}$ and $\mathrm{EC}$ and nitrogen, phosphorus and potassium, as reported in (14). Soil characteristics affecting soil fertility were identified for crop cultivation. The estimation estimates for different soil traits are multiplied together for the purpose of obtaining the final assessment of the fertility assessment by which the soil suitability classification is determined by the equation (17):

$\mathbf{F}=\mathrm{T} * \mathrm{OM} * \mathrm{CEC} * \mathrm{CaCO3}^{*} \mathrm{~N} * \mathrm{P} * \mathrm{~K} * \mathbf{p H} * \mathbf{E C} * \mathrm{ESP}$

Where:

$\mathrm{F}=$ Fertility.

$\mathrm{T}=$ Texture.

$\mathrm{OM}=$ Organic Matter

$\mathrm{CEC}=$ Cation Exchangeable Capacity

$\mathrm{CaCO} 3=$ Calcium Carbonate

$\mathrm{N}=$ Nitrogen

$\mathrm{P}=$ Phosphor

$\mathrm{K}=$ Potassium.

$\mathrm{pH}=\mathrm{Ph}$

$\mathrm{EC}=$ Electric Conductivity

$\mathrm{ESP}=$ Exchangeable Sodium Percentage

The values of the evidence are calculated from special tables prepared in advance as shown in the tables below

Table1. Types of Texture and standard values of the grain Index

\begin{tabular}{|cc|}
\hline $\begin{array}{c}\text { Index } \\
\text { value }\end{array}$ & SOIL TEXTURE \\
\hline 105 & SILTY CLAY LOAM \\
100 & SILTY CLAY OR CLAY \\
95 & LOAM OR SILTY LOAM \\
85 & CLAY LOAM OR LOAM \\
75 & SANDY CLAY OR \\
85 & SANDY CLAY LOAM \\
55 & SANDY LOAM \\
45 & LOAMY SAND \\
& SAND \\
\hline
\end{tabular}

Table2. Status of soil organic matter and standard values of its index

\begin{tabular}{|cc|}
\hline Index value & O.M $(\mathrm{gm} . \mathrm{Kg}-1)$ \\
\hline 0.50 & Less than 10 \\
0.80 & $(14-10)$ \\
0.9 & $(20-14)$ \\
1 & $(20<)$ \\
\hline
\end{tabular}

Table3. Standard values for the CEC directory

\begin{tabular}{|cc|}
\hline Index value & $\mathrm{CEC}\left(\mathrm{Cmol}_{\left.\mathrm{c} \cdot \mathrm{kg}^{-1}\right)}\right.$ \\
\hline 0.5 & $10-15$ \\
0.7 & $15-20$ \\
0.9 & $20-25$ \\
1 & $25<$ \\
\hline
\end{tabular}

Table4. Standard Index values for different levels of lime ratios in soil

\begin{tabular}{|cc|}
\hline Index value & EC $\left(\mathrm{dS}^{-m^{-1}}\right)$ \\
\hline 1 & $4-0$ \\
0.9 & $8-5$ \\
0.6 & $16-8$ \\
0.3 & $16<$ \\
\hline
\end{tabular}

Table5. ESP ratio and standard values for its directory

\begin{tabular}{|cc|}
\hline Index value & ESP $(\%)$ \\
\hline 0.9 & Less 8 \\
1 & $16-8$ \\
0.9 & $25-16$ \\
0.6 & $25<$ \\
\hline
\end{tabular}

Table6. Standard Index values for different levels of salinity

\begin{tabular}{|cc|}
\hline Index value & $\mathrm{EC}\left(\mathrm{dS} . \mathrm{m}^{-1}\right)$ \\
\hline 1 & $4-0$ \\
0.9 & $8-5$ \\
0.6 & $16-8$ \\
0.3 & $16<$ \\
\hline
\end{tabular}


Table7. The standard Index for different levels of salinity is the standard Index for different levels of soil available $N, P$, and $K$

\begin{tabular}{|cccc|}
\hline Index value & K & P & N \\
& & ppm & \\
0.5 & $100>$ & $10>$ & $20>$ \\
0.7 & $160-100$ & $10-18$ & $20-30$ \\
0.9 & $250-160$ & $18-30$ & $30-45$ \\
1 & $250<$ & $30<$ & $45<$ \\
\hline
\end{tabular}

Table8. Standard soil pH values

\begin{tabular}{|cc|}
\hline Index value & pH \\
\hline 0.7 & $6>$ \\
1 & $8-6$ \\
0.7 & $8<$ \\
\hline
\end{tabular}

Table9. Fertility of soil varieties with evidence of their validity

\begin{tabular}{|c|c|c|c|}
\hline $\begin{array}{l}\text { Validity } \\
\text { guide } \\
\text { value }\end{array}$ & Symbol & Class & $\begin{array}{c}\text { Class } \\
\text { degree }\end{array}$ \\
\hline$<80$ & F1 & Very fertile & $\begin{array}{l}\text { First } \\
\text { Class }\end{array}$ \\
\hline $80-60$ & F2 & fertile & $\begin{array}{c}\text { Second } \\
\text { Class }\end{array}$ \\
\hline $60-40$ & F3 & $\begin{array}{l}\text { Moderately } \\
\text { fertile }\end{array}$ & $\begin{array}{l}\text { Third } \\
\text { Class }\end{array}$ \\
\hline $40-20$ & F4 & $\begin{array}{l}\text { slightly } \\
\text { fertile }\end{array}$ & $\begin{array}{c}\text { Fourth } \\
\text { Class }\end{array}$ \\
\hline$>20$ & $\mathbf{N}$ & Non fertile & $\begin{array}{l}\text { Fifth } \\
\text { Class }\end{array}$ \\
\hline
\end{tabular}

Database building and map production (GIS): Make a fertility map using the ArcGIS V10.4 program based on the data for the study area. A database based on samples taken and stabilized by GPS (German) was carried out and laboratory measurements were made to estimate some of the physical and chemical properties described above, a database was created for each of the study areas. The data obtained after the laboratory analysis of the samples were linked to the spatial data in the Shape File (points). Based on the technique of Kriging, a large part of the study center representing some measured traits, the soil fertility map was produced for the study area using soil fertility assessment criteria and criteria based on the use of geographic information systems software

\section{RESULTS AND DISCUSSION \\ 1.Physical characteristics \\ Texture}

The results indicates the soil texture predominance of the silty clay loam in the study area is $100 \%$ from total area, which mean there is no fig. to present it in ArcGIS10.4 program because there is no varies in texture classes in study area. The texture ranged from fine moderately to moderately in the study area, but most tended to silty clay loam. The Texture is a basic and important attribute in which most of the soil's biological characteristics are associated with the same time degree of change over time, compared with the rest of the qualities (5), Soil texture is particularly important in assessing soil suitability for agriculture. And it has a strong relationship to know the soil's ability to retain water and how well it is prepared. Fine texture keeps water longer than coarse texture; the texture has an effect on some physical and chemical properties of soils, such as tillage, cation exchangeable capacity, nutrient availability, and drainage, so it is a determinant factor for soil fertility and crop cultivation. The texture is the final product of structure change. Thus, the soil of the study area is generally located in sedimentary soils which contain silt and clay.

\section{Chemical characteristics CEC}

It is an important factor of soil fertility, and reflects the soil's ability to retain and prepare nutrients for plants when needed. Figure 1, 3 shows CEC in the study area was 24.6-28.5, 28.5-29 and 29-31 $\mathrm{Cmol}_{\mathrm{C}} \cdot \mathrm{kg}^{-1}$ by area 24.81, 81.25 and $57.50 \mathrm{~h}$ with percentage $15.22,49.84$ and $35.27 \%$ respectively, from total area. These ratios are good because the texture is silt clay loam, containing good amounts of clay and has been a determining factor for soil suitability for growing crops. As it is gives a good idea of soil ability to hold cations added fertilizer or solvents such as potassium, magnesium and others.

\section{$\mathrm{CaCO}_{3}$}

Figure 2, 3 shows Calcium carbonate in the study area was 201-220, 220-240, 240-260 and 260-280 gm. $\mathrm{kg}^{-1}$ by area $0.29,21.56,112.65$ 
and $38.63 \mathrm{~h}$ with percentage $0.16,12.46,65.11$ and $22.32 \%$ respectively, from total area. It is an important mineral present in arid and semiarid regain where it is deposited when the rain is limited or low, and it is deposited more often when evaporation is higher than rainfall. One of the most important sources of calcium carbonate is the decomposition of limestone, dolomite and other calcite deposits as it dissolves and re-deposits it as a secondary metal in the dry seasons. It may result from the decomposition of calcium-containing primary minerals, when Carbon dioxide is present in the atmosphere, Calcium carbonate may precipitate when drought is available. Another source of secondary calcium carbonate is found in the soil through groundwater when it is not far away from the surface of the earth and rich in calcium carbonate dissolved, through the property of poetry and evaporation, it is deposited in the soil profile, which occurs in sedimentary soil. The average amount of lime $(10-25 \%)$ has a positive effect for the soil suitability for irrigation, but if it increases, the suitability gradually decreases to reach $50 \%$ or more as this leads to a decline in the soil's susceptibility to productivity. $\mathrm{CaCO}_{3}$ affects nutrient availability for plant growth, and nutrient deficiencies such as phosphorus, iron, and zinc are common in calcareous soils due to high soil $\mathrm{pH}$. Moreover, the high ratio of secondary calcite leads to higher uses of fertilizers. The soil containing a high percentage of lime is less than the productivity of the soil containing a low percentage of lime if the rest of the factors are equal. All the soils are characterized by relatively high quantities of lime, because the origin of calcareous deposits is an important factor in soil fertility and the identification of crop cultivation.

\section{Ph}

Figure 4,7 shows a good $\mathrm{pH}$ values in study area was 7.6-7.7 and 7.7-7.83 by area 47.86 and $125.27 \mathrm{~h}$ with percentage 27.66 and $72.41 \%$ respectively, from total area. This was considering neutral to moderately alkaline soils. The high contain of calcium carbonate due to upper $\mathrm{pH}$ into alkalinity. $\mathrm{pH}$ is an essential factor for growing crops, soil fertility and very important to fertility assessment because the important effect in physical, chemical, fertility characteristics and nutrient availability, the $\mathrm{pH}$ range at study area for most crops and nutrients, so the effect that was less than regression for soil fertility and crops planting $(3 ; 4 ; 16)$.

\section{Electric Conductivity}

The results showed Fig. $(5,7)$ low and average salinity values in the study area was $2.83-4$, 45 and 5-6.7 ds.m ${ }^{-1}$ by area $40.16,118.83$ and $14.14 \mathrm{~h}$ with percentage $23.21,68.68$ and $8.17 \%$ respectively, from total area. This percentage of salinity is a small determinant of soil fertility and crop cultivation. These results confirm the role of physical properties affecting the movement of water within the soil profile and the accompanying movement of soluble salts. The state of deterioration structure in saline soils and its negative impact on porosity, soil permeability and its reflection on the amount of salts accumulated in soil. The more soil porous the better improve the movement of water and thus reduce the state of salt accumulation.

\section{Exchangeable Sodium Percentage}

Results in Figure 6, 7 indicate that ESP was 812 and $12-16 \%$ by area 113.88 and $59.25 \mathrm{~h}$ with percentage 65.82 and $34.24 \%$ respectively, from total area. The proportion less than $16 \%$ is not a determinant or influential factor for crop growth, while the proportion of more than $16 \%$ is a very limited factor for soil fertility and crop cultivation (17). The increase of ESP for $16 \%$ of the soil is characterized by bad natural characteristics of the difficulty of permeability, water during the poor drainage, the difficulty of dryness and vice versa, when falling below $16 \%$. The importance of planned agriculture to ensure that accumulation of sodic compounds is not within the range of plant root, but outside the critical depth of any soil. The neglect of mulching, maintenance and soil reclamation seriously contributes to increasing the likelihood of soil exposure to the risk of sodia, which begins seriously as the ESP From 16\% and above. (9) pointed to the importance of continuous monitoring of changes of ESP in the soil to ensure the expansion of soil area where increases by $16 \%$, as the expansion of these soils and their proximity to agricultural soils can affect The soil is treated with sodium biodegradation at a standard time, especially 
when a scientific plan for water management in the field is not followed in terms of providing water suitable for irrigation, suitable drainage of the water and its bearing dissolved and exchanged sodium outside the soil profile.

\section{Fertility characteristics Organic matter}

Figure 8, 11 shows soil organic matter in the study area was 10.1-13, 13-13.5 and 13.5-15.3 gm. $\mathrm{kg}^{-1}$ by area $69.23,69.02$ and $34.88 \mathrm{~h}$ with percentage $40.01, \quad 39.89$ and $20.16 \%$ respectively, from total area. As it is a natural proportion under the conditions of dry climate and lack of natural plants and organic matter is an essential factor for growing crops and soil fertility, which is an important factor in determining the appropriateness of future cultivation of crops. The high soil content of organic matter is the best indicator of successful management in arid and semi-arid regions with vegetation cover, The extent to which farmers follow a scientific plans to preserve soil fertility, to maintain certain factors and conditions of chemical deterioration in the soil, the high content of soil organic matter reduce a soil degradation because of its benefits in maintaining soil fertility and nutrient stability, The possibility of adopting the pattern of continuous agriculture as well as improving the soil physical properties, which is linked primarily to the flow of soil and plant growth.

Nitrogen The results showed Fig. $(9,11)$ average values of available nitrogen in the study area, was 24-35, 35-40 and 40-54 mgm. $\mathrm{kg}^{-1}$ by area $5.10,109.74$ and $58.29 \mathrm{~h}$ with percentage $2.94,63.43$ and $33.69 \%$ respectively, from total area. Nitrogen is a determinant factor for soil fertility and crop cultivation because of its direct effect on the growth and activity of various plants, as it is one of the necessary plant nutrients, which needs large quantities and has an impact on increasing the production of different crops. The lack of it works on the poor quality of the quantity, so it conceding a specific factor of soil fertility, and varies from soil to soil depending on the soil conditions, as well as losses and leaching, which works to lose the nitrogen from the soil, which affects the soil fertility.

\section{Phosphorus}

The results in Figure 10, 11 shows average values of available phosphorus in the study area, was 11-13.5, 13.5-15.5, 15.5-18 and 18$21.3 \mathrm{mgm} . \mathrm{kg}^{-1}$ by area $22.81,92.80,54.83$ and $2.68 \mathrm{~h}$ with percentage $13.18,53.64,31.69$ and $1.54 \%$ respectively, from total area. Phosphorus is a determining factor for soil fertility and crop cultivation; this is because the Phosphorus is important for the growth of the plant (2). The addition of Phosphorus to soil is subjected to many sedimentation and adsorption processes, which reduce it to plant, since the study areas contain amounts of Calcium carbonates that work on adsorption of phosphorus and composition of sediments. In the case of organic matter, the adsorption of phosphorus by the soil is little or none and thus increases the plant available by increasing its concentration in the soil.

\section{Potassium}

The results in Figure (12) show average values of available potassium in the study area, was $161-185,185-200$ and $200-220$ mgm. kg ${ }^{-1}$ by area $13.46,124.42$ and $35.24 \mathrm{~h}$ with percentage $7.78,71.91$, and $20.36 \%$ respectively, from total area. Potassium is a determinant factor for soil fertility and crop cultivation, although the soil was not added by the farmers but the potassium level was very high in the study areas because the soil potassium content is good because it is mostly Si.C.L, which contains high clay percentages that works on the potassium fixation which may be ready for the plant over time, this is observed in the study area containing only Si.C.L. texture where the potassium content increased by a small percentage. 


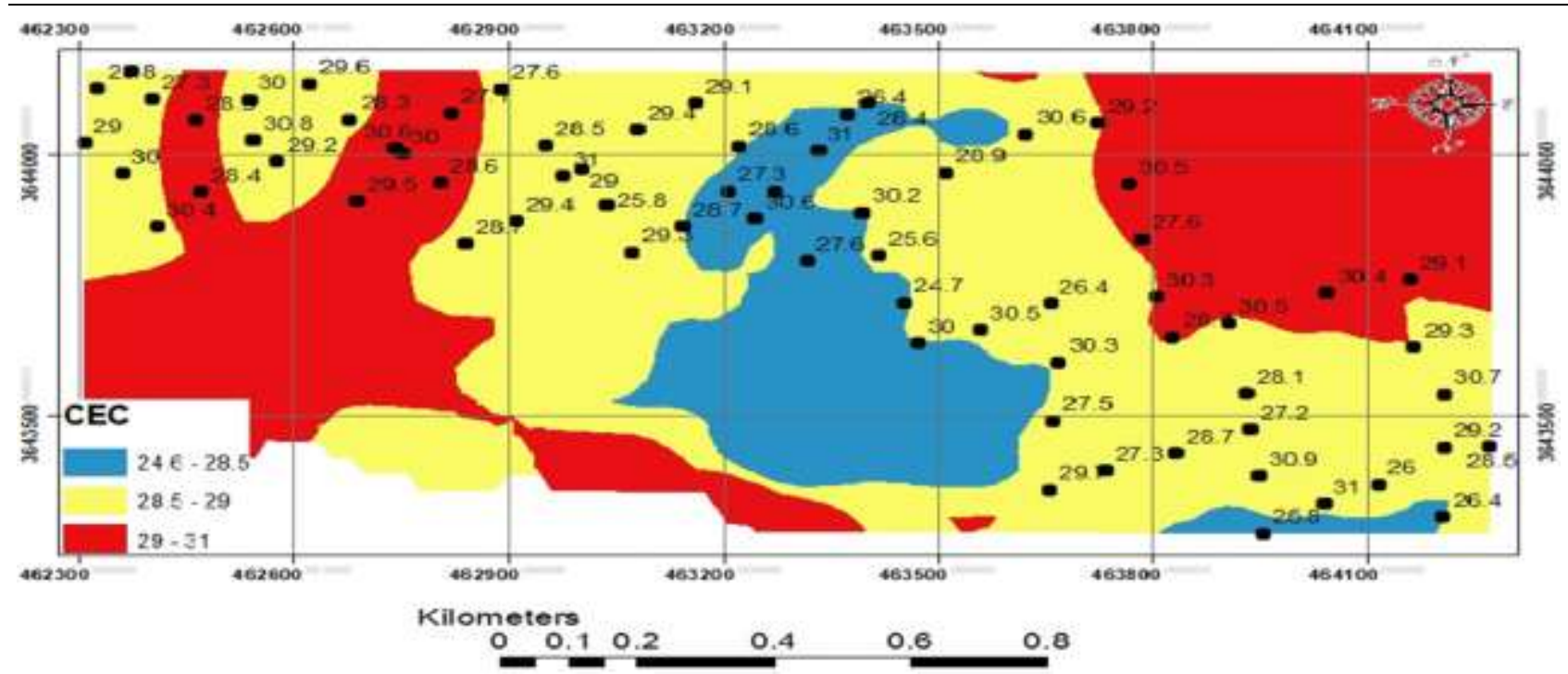

Figure 1. map of CEC distribution $\left(\mathrm{CmoleKg}_{4637500}^{-1}\right)$

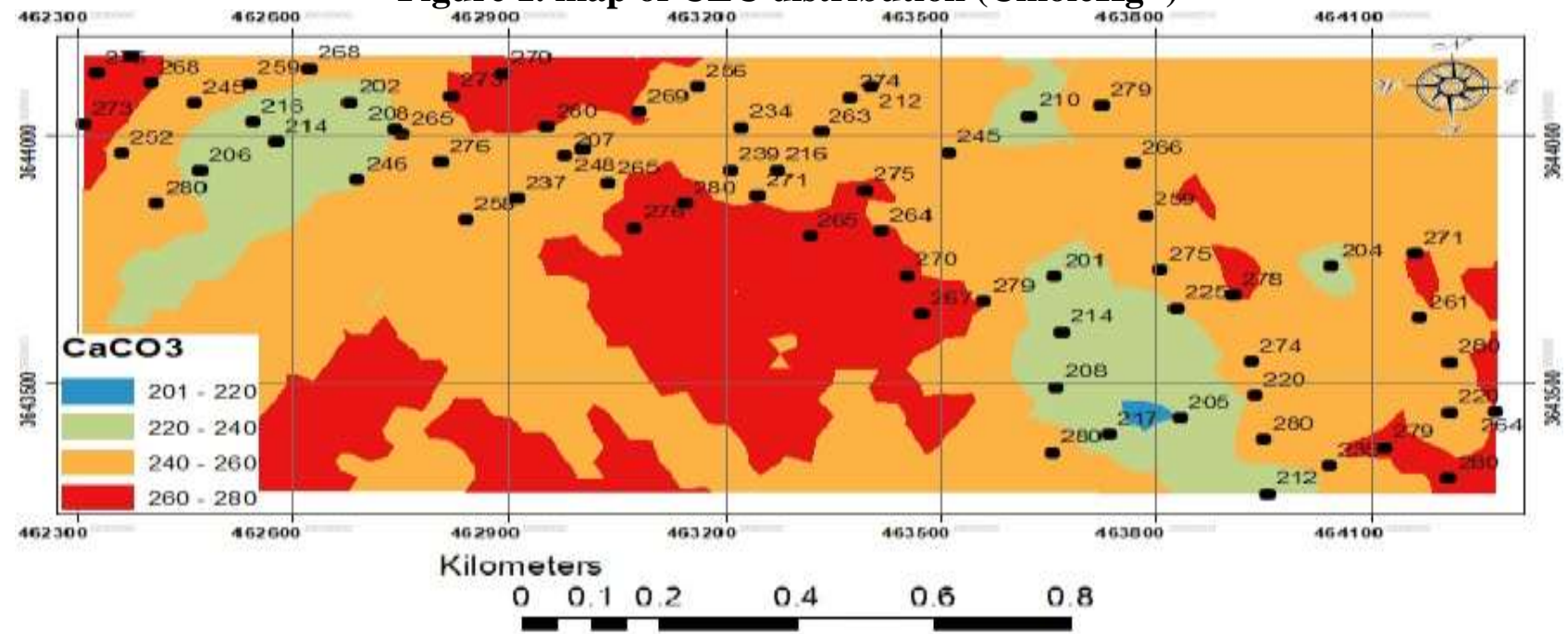

Figure 2. map of $\mathrm{CaCO}_{3}$ distribution $\left(\mathrm{gmKg}^{-1}\right)$
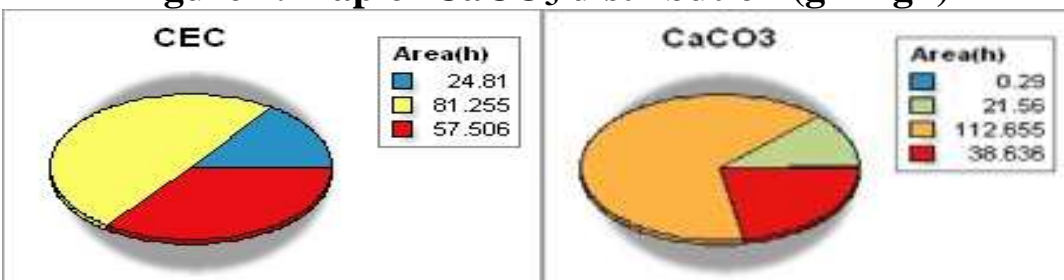

Figure 3. area of $\mathrm{CEC}$ and $\mathrm{CaCO}_{3}$

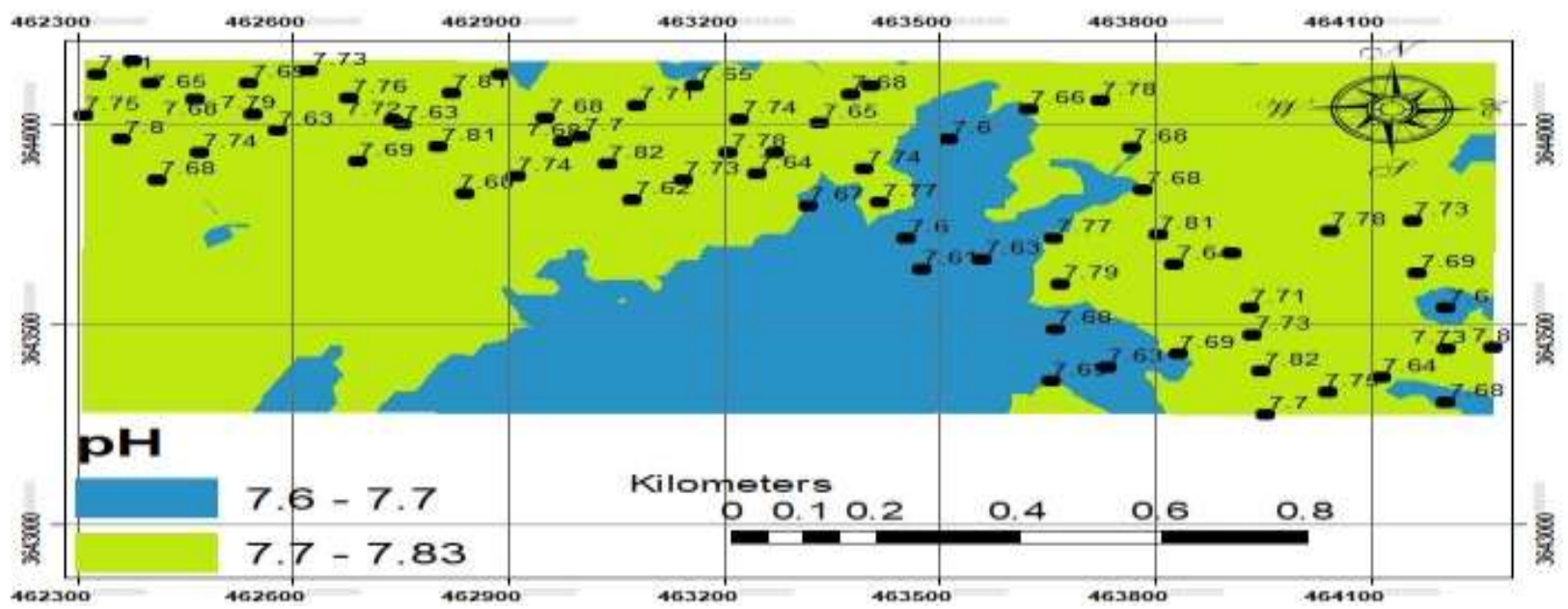

Figure 4. map of pH distribution 

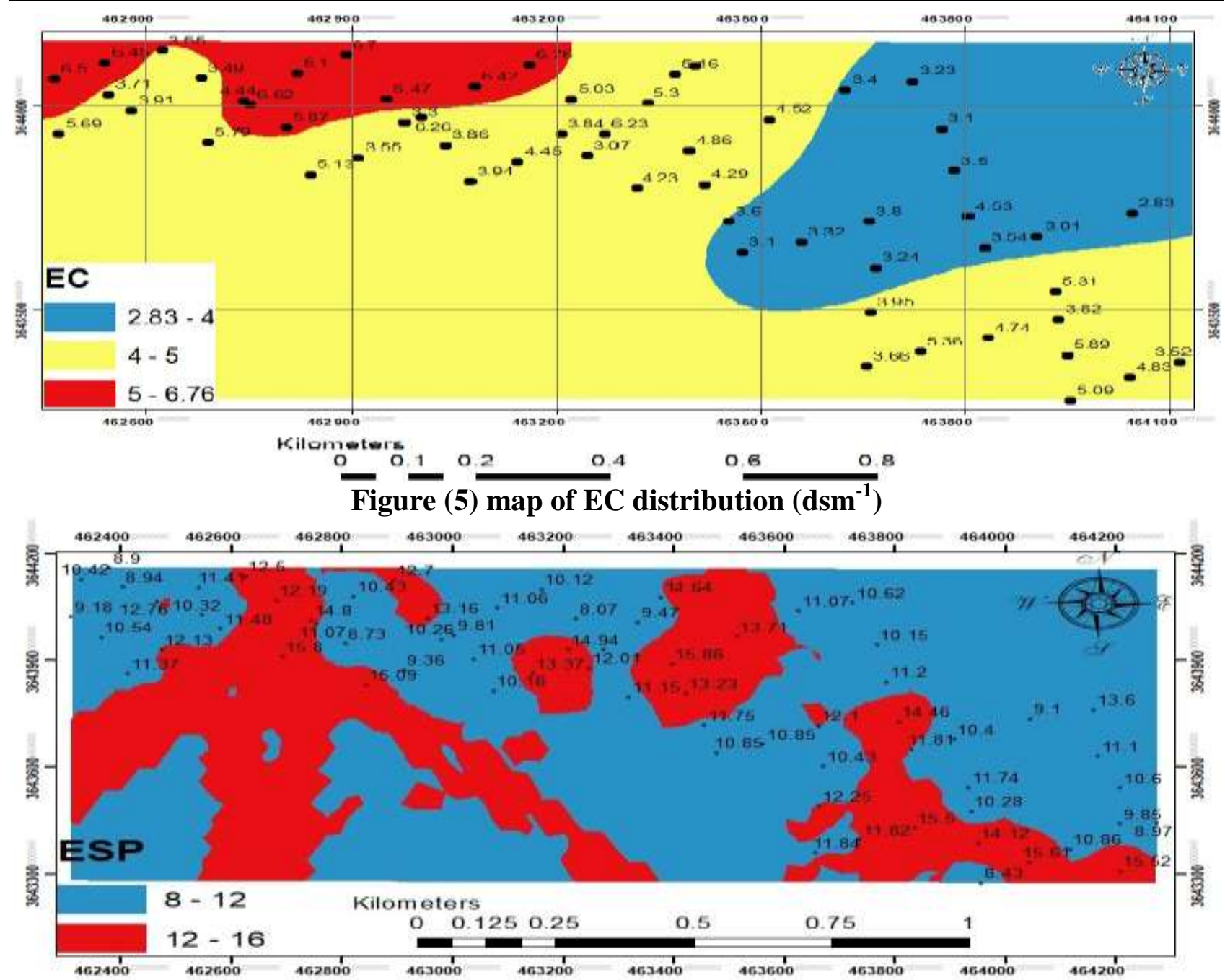

Figure (6) map of ESP distribution (\%)
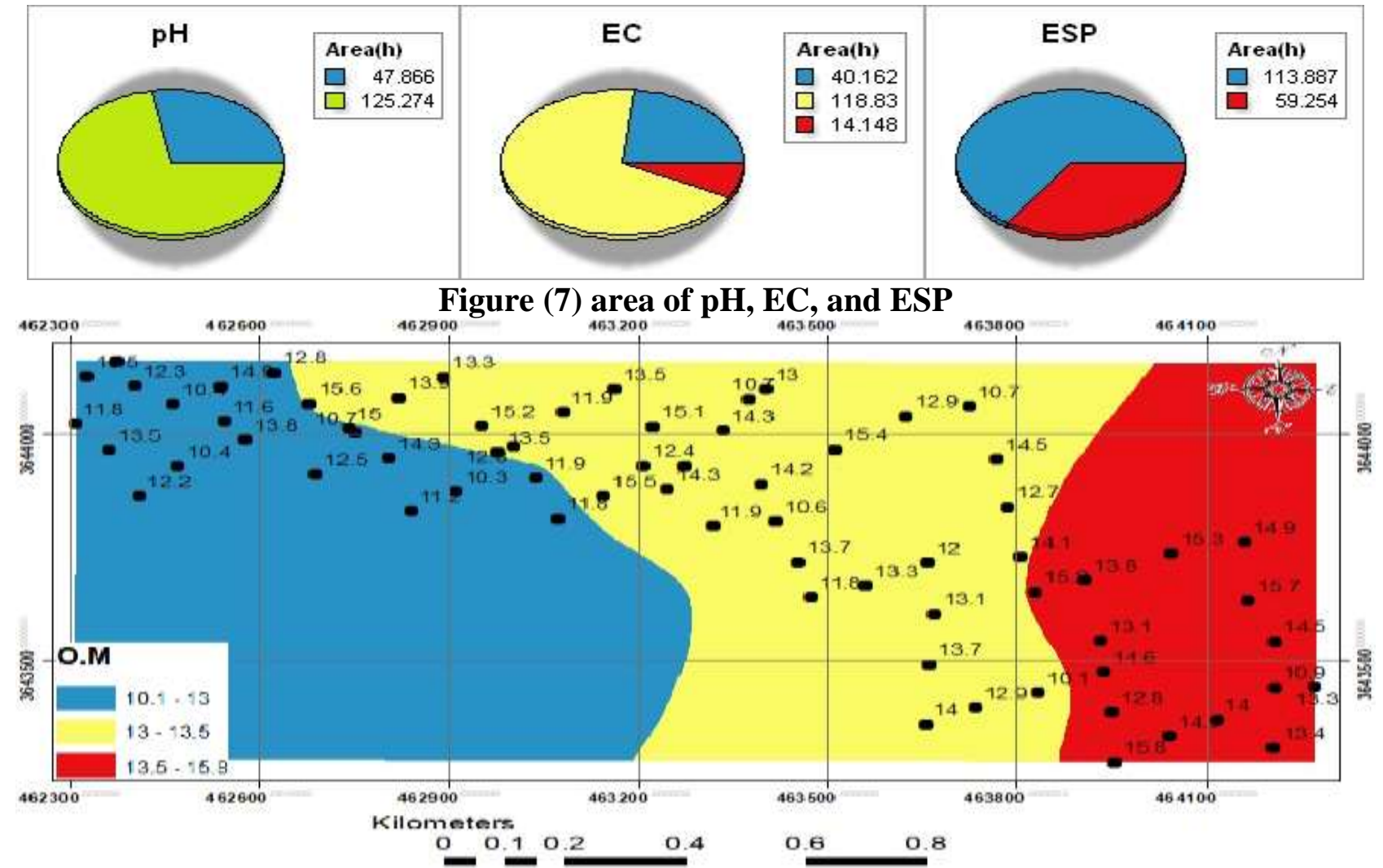

Figure (8) map of O.M distribution $\left(\mathrm{gmkg}^{-1}\right)$ 


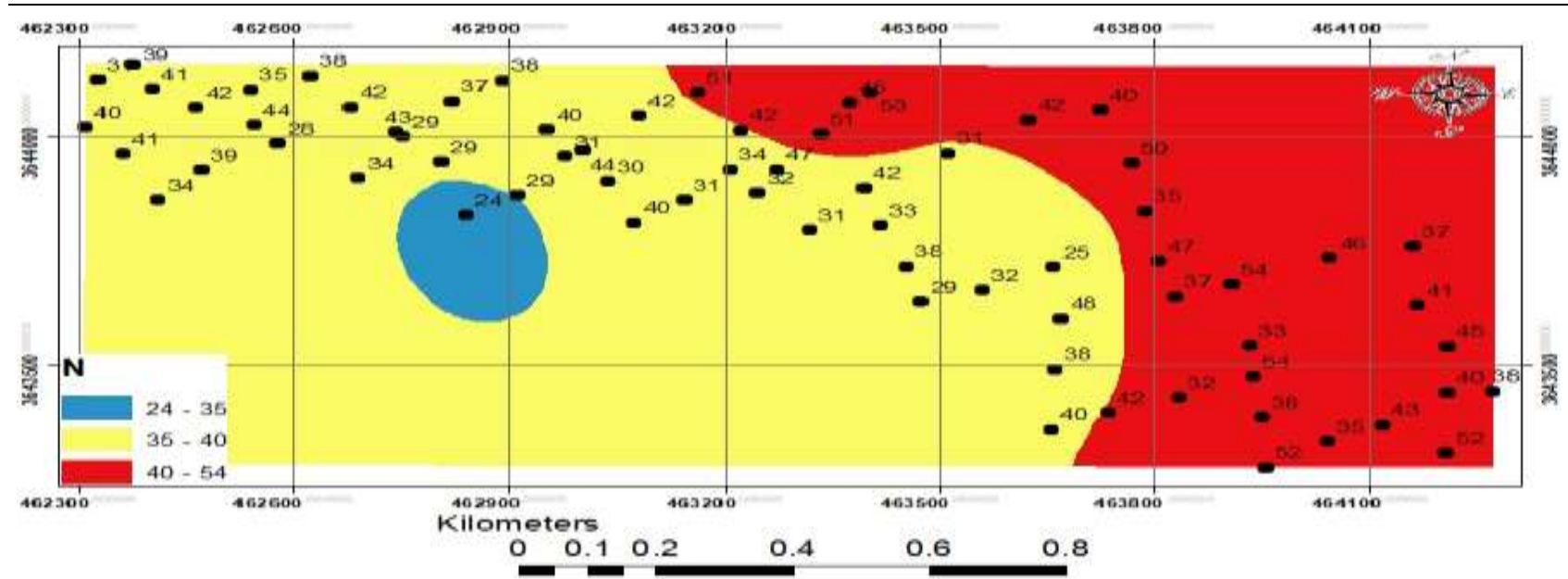

Figure (9) map of available Nitrogen distribution $\left(\mathrm{mgmkg}^{-1}\right)$

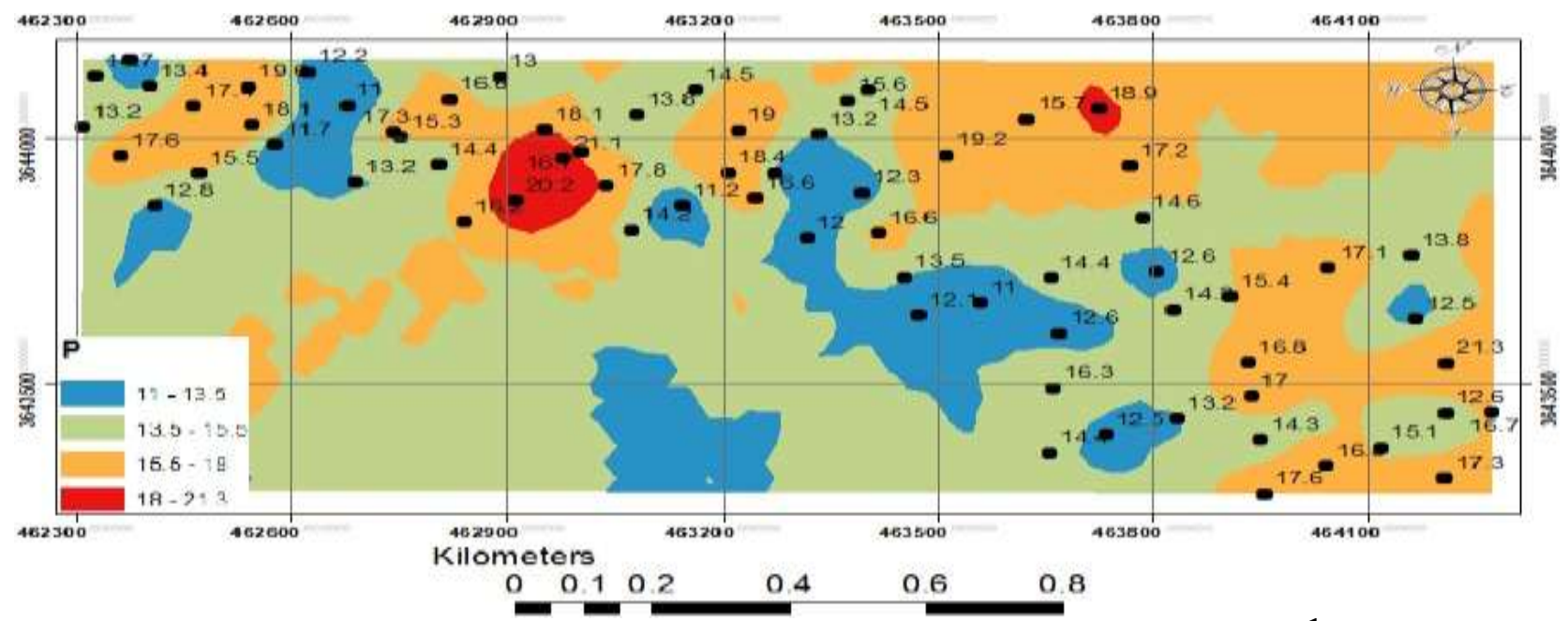

Figure (10) map of available Phosphorus distribution (mgmkg ${ }^{-1}$ )

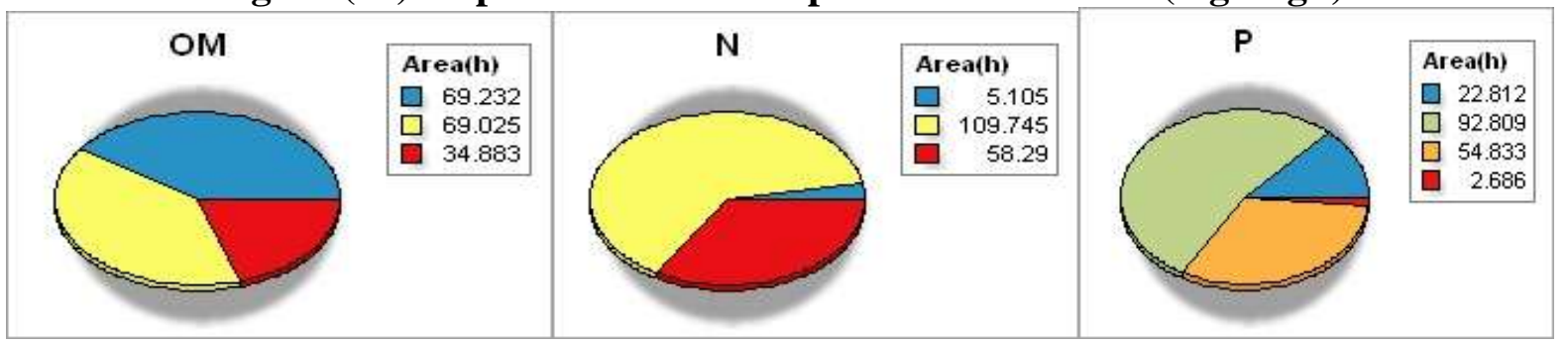

Figure (11) area of O.M, $N$ and $P$ 

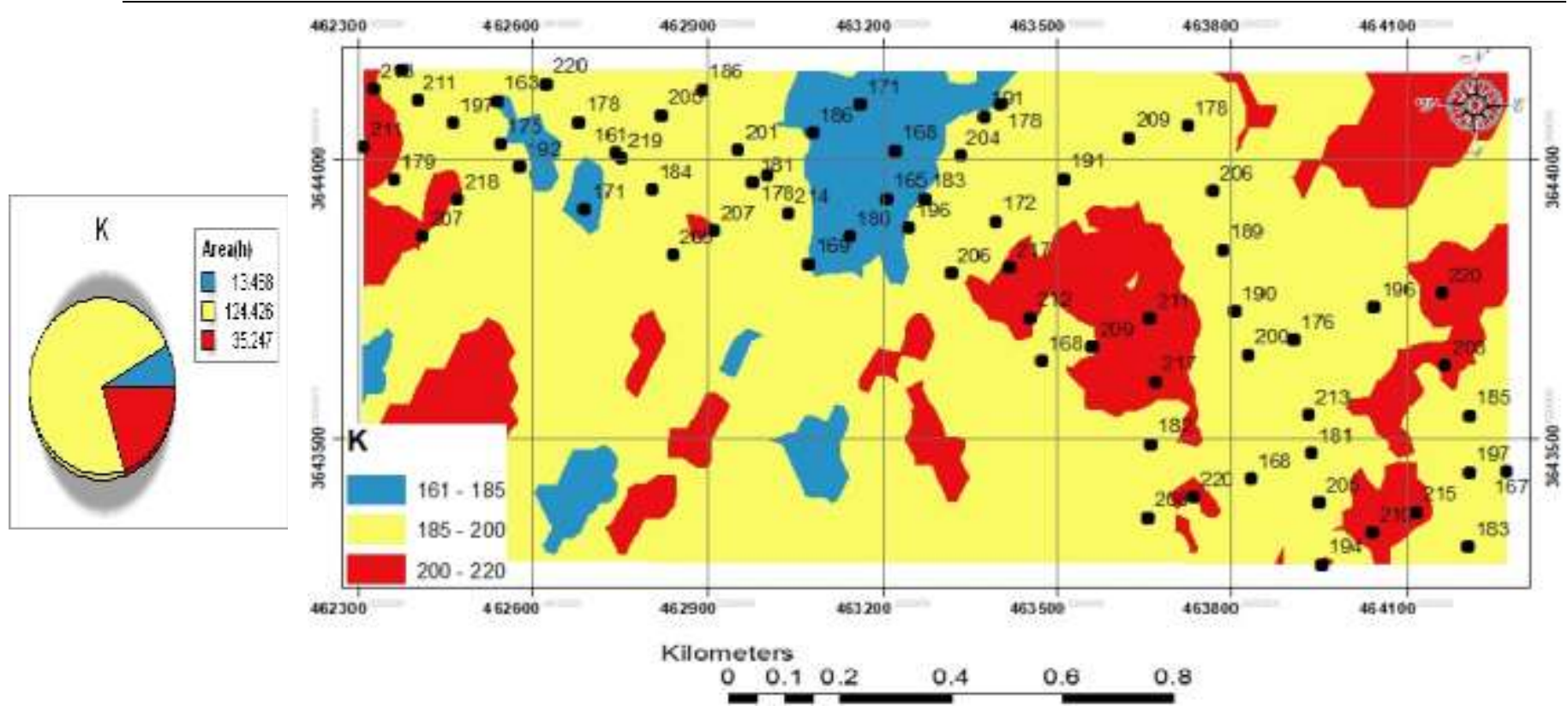

Figure (12) map of available Potassium distribution $\left(\mathrm{mgmkg}^{-1}\right)$ and its area
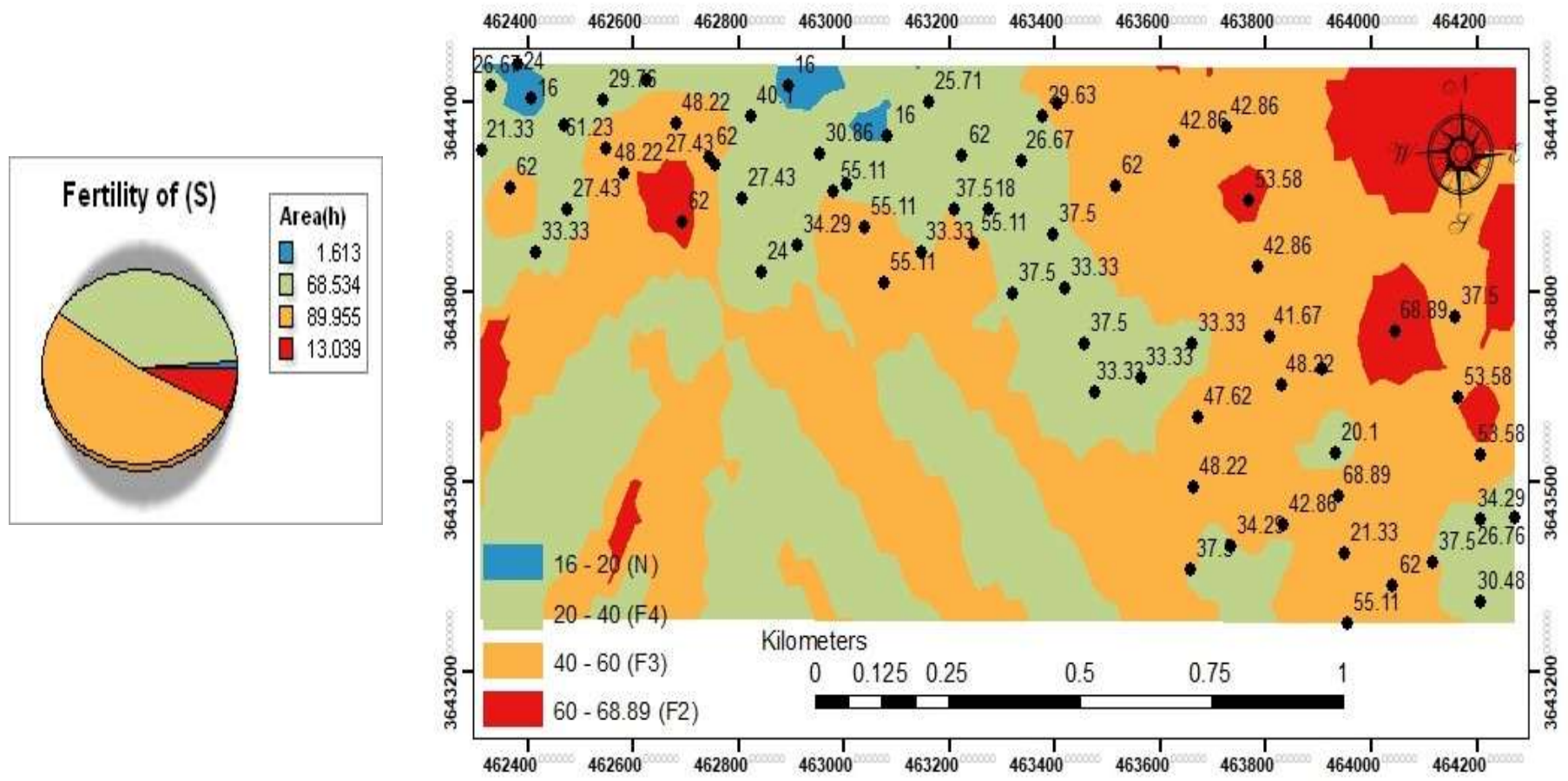

Figure (13) map of classes fertility assessment and its area

\section{Evaluation of soil fertility for crop cultivation}

The results of the study (Fig. 13) indicate that there are four types of fertility assessment according to the standard method of beating in the study area:

1- Very fertile F1

This class does not exist in the study area because it does not contain all the optimal indicators included in the fertility assessment ideally, which led to disappeared of this class

2- fertile F2

This class includes a small area of the study area, with an area of $13.04 \mathrm{~h}$, equivalent to
$7.53 \%$ of the total area (Fig. 13). It has silty clay loam texture, high organic matter, neutral $\mathrm{pH}$, moderately $\mathrm{CaCO} 3$, high $\mathrm{CEC}$, high contain NPK, low ECe, and low ESP. Productivity has reached $62-68 \%$, These values place these areas within the fertile soils 3- moderately fertile F3

This class includes most of the area of the study area, with an area of $89.95 \mathrm{~h}$, equivalent to $51.99 \%$ of the total area (Fig. 13). The soil is characterized by silty clay loam texture, low organic matter, neutral $\mathrm{pH}$, high $\mathrm{CaCO} 3$, high 
CEC, high contain NPK, low ECe, and low ESP. Productivity has reached $42-55 \%$ and these values place these areas within the moderately Fertility Soil class

\section{Slightly fertile F4}

This class includes approximately one-third of the study area, with an area of $68.53 \mathrm{~h}$, equivalent to $39.61 \%$ of the total area (Fig. 13). The soil is characterized by silty clay loam texture, moderately organic matter, neutral $\mathrm{pH}$, high $\mathrm{CaCO}$, high $\mathrm{CEC}$, high contain NPK, moderately ECe, and low ESP. It has reached $20-40 \%$ productivity and these values place these areas within soil slightly fertile class

\section{Non-fertile N}

It covers a very small area of the study area, with an area $1.61 \mathrm{~h}$, equivalent to $0.93 \%$ of the total study area (Fig. 13). The main reason for the low productivity of this class is low organic matter, high $\mathrm{CaCO} 3$ and high ECe.

\section{REFRENCES}

1. AbdelRahman, M. A. E.; A. Natarajan; C. A. Srinivasamurthy and R. Hegde. 2016. Estimating soil fertility status in physically degraded land using GIS and remote sensing techniques in Chamarajanagar district, Karnataka, India. The Egyptian Journal of Remote Sensing and Space Sciences. 19. 95108

2. Al-Dilaimi, H. Y. 2006. Effect of phosphorus applied foliary and mixed in soil on the availability and uptake of $\mathrm{P}, \mathrm{Zn}$, and $\mathrm{Cu}$ by Maize. The Iraqi J. of Agric. Sci. 37(2): 1522

3. Ali, N. S., H. S. Rahi and A. Abdel Razak. 2014. Soil Fertility. Arab Society Library for Publishing and Distribution. Amman, Dar Al Kuttab Al-Sallami for Printing, Publishing and Distribution. Baghdad. (In Arabic). pp: 53- 68

4. Al-Naimi, S. N. 1999. Soil Fertility and Fertilizers. Ministry of Higher Education and Scientific Research, Mosul University. (In Arabic). pp: 118-121

5. Al-Okidi, W. K. 1990. Soil and Land Use Policy. Ministry of Higher Education and Scientific Research - University of Baghdad. (In Arabic). pp: 85-123

6. Al-Shujairy, Q. T. A. and N. S. Ali. 2017. Prediction of soil available phosphorous content using spectra-radiometer and gis in southern of Iraq. The Iraqi J. of Agric. Sci. 48(Special Issue): 171-177

7. Black, C.A. 1965. Methods of soil analysis. Part1. Physical and Mineralogical properties Am. Soc. Agron., 9.Madison, Wisconsin, USA. pp: 1022

8. Canada Centre for Remote Sensing. 2010. fundamental of remote sensing, natural resources. pp: 25-32

9. Gaemi, M., A. R. Astaraei, S. H. Sanaeinejad and H. Zare. 2013. Using Satellite data for soil cation exchange capacity studies. Int. Agrophys. 27: 409- 417

10. Hamad, A. I. 2013. The Use of Remote Sensing (RS) and Geographic Information System (GIS) for Change Detecting Spatial and Temporal Variability of Soil Salinity in Al-Latifiya Project, Iraq Ph.D. Dissertation. Dept. of Soil Sci. Coll. of Agric. Baghdad University

11. Hameed, A. O. and A. I. Hamad. 2015. The Use of Spatial Analysis for Soil Map produced by Geographic Information System (GIS) in South of Iraq. The Iraqi J. of Agric. Sci. 15 (1): 210-224

12. Page, A. L. 1982. Method of soil analysis. Part 2. Chemical and Microbiological Properties. Am. Soc of Agron. Madison, Wisconsin. pp: 1159

13. Parry, M.A.J., J. Flexas, and H. Medrano. 2005. Prospects for crop production under drought: research priorities and future directions. Ann. Appl. Biol., 147, 211-226.== 14. Salem, S. J. and N. S. Ali. 2017. Directory of Chemical Analyzes of Soil, Water, Plants and Fertilizers. Ministry of Higher Education and Scientific Research. Coll. of Agriculture University of Baghdad. (in arbic). pp: 407

15. Soil Survey Staff. 2006. Keys to Soil Taxonomy. Tenth edition United State Department of agriculture natural recourses conservation service - SW. Washington, D.C, USA. 184-203

16. Spozzito. 2012. Soil chemistry. Translation of Nour al - Din Ali Shawqi and Shafiq Jalab Salem. Ministry of Higher Education and Scientific Research - University of Baghdad. (In Arabic). pp: 213-227

17. Sys, Ir .C., E.Van, J. Ranst, Debaveye and F. Beernaert. 1980. Land Evaluation. Belgium General Administration for Development 
Cooperation .Agriculture Publication. pp: 6475

18. Thomas U., P. Delfosse, C. Bossung, F. Ronellenfitsch, F. Mayer, M. Schlerf, M. Machwitz, and L. Hoffmann. 2013. Retrieving the bioenergy potential from maize crops using hyperspectral remote sensing, J. Remote Sensing 5:254-273

19. Wheib, K. A. 2012. Spectral Reflectance Properties of Soil Surface and land cover of alSalman depression in southern Iraq. The Iraqi J. of Agric. Sci. 43(4) (Special Issue): 129140. 